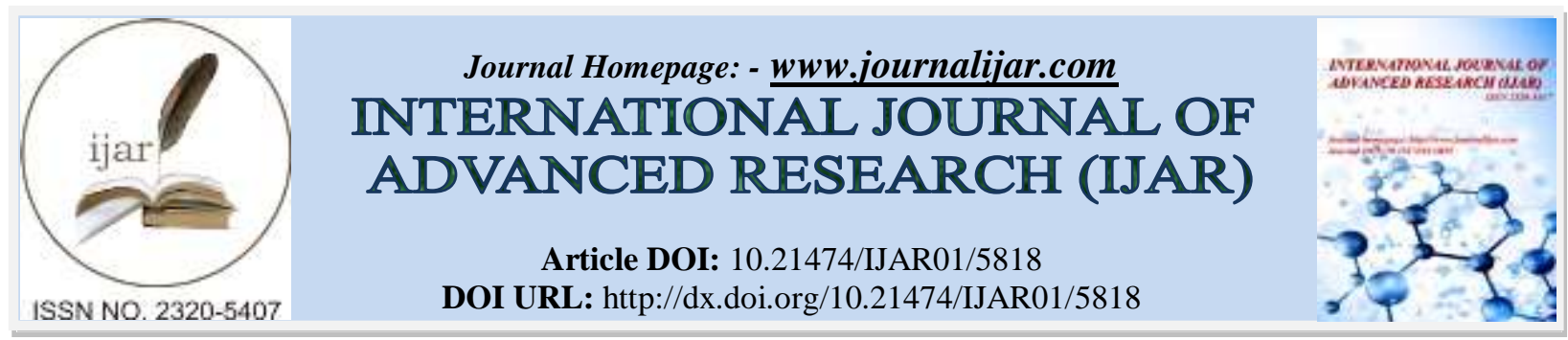

RESEARCH ARTICLE

\title{
NANOORAVIA KAYYURENSE (POACEAE) - A NEW SPECIES FROM EPHEMERAL WETLANDS ON LATERITIC HILLOCKS OF NORTH KERALA, INDIA.
}

\section{${ }^{*}$ T. Shaju ${ }^{1}$, M. Rajendraprasad ${ }^{1}$, M. P. Rijuraj ${ }^{1}$ and M. K. Ratheesh Narayanan ${ }^{2}$.}

1. Plant Systematics and Evolutionary Science Division, Jawaharlal Nehru Tropical Botanic Garden and Research Institute, Karimancode P.O, Palode, Thiruvananthapuram - 695 562, Kerala, India.

2. Department of Botany, Payyanur College, Edat P. O., Kannur-670327, Kerala, India.

\section{Manuscript Info}

Manuscript History

Received: 09 September 2017

Final Accepted: 11 October 2017

Published: November 2017

Key words:-

Laterite, Nanooravia, Ephemeral wetlands.

\section{Abstract}

A new species of genus Nanooravia Kiran Raj \& Sivad. (Poaceae) is described and illustrated from the lateritic hillocks of Kasaragod district, Kerala, India. The species is proved to be distinct from Nanooravia santapaui (M. R. Almeida) Kiran Raj \& Sivad., the only hitherto known species of the genus. A detailed description of the taxon is provided with illustration and photographs to facilitate its identification.

Copy Right, IJAR, 2017,. All rights reserved.

\section{Introduction:-}

Nanooravia (Poaceae-Panicoideae-Andopogoneae-Dimeriinae) is a unispecific genus recently described by Kiran Raj et al. (2013) from the southern Western Ghats in India. While carrying out taxonomic revision of the subtribe Dimeriinae Hack. ex C.E. Hubb.(1934) in Peninsular India (2008), they observed that two conspecific species $D$. santapaui M. R. Almeida and D. keralae N.C. Nair, Sreek. \& V.J. Nair, showed several features distinct from the characteristics of the genus Dimeria R. Br. Based on detailed morphological analysis, the new genus Nanooravia was proposed. With the recognition of Nanooarvia gen. nov., the subtribe Dimeriinae now comprises of two genera, viz. Dimeria and Nanooravia. The new genus Nanooavia represents only one species N.santapaui, which is endemic to southern Western Ghats, having distribution in the lateritic plateaus of Kannur and Kasaragod districts of north Kerala, and Dakshin and Uttar Kannada districts of Karnataka.

During a recent field exploration carried out in the lateritic hilly regions of north Kerala, the authors collected an interesting specimen of Nanooravia from ephemeral wetlands on the lateritic rocks in Kayyur village of Kasaragod district. On critical morphological study, the specimen proved to be distinct from $N$. santapaui, the only hitherto known species of the genus. The taxon new to science is described and illustrated here.

Nanooravia kayyurense Shaju, Rajendraprasad, Rijuraj \& Ratheesh Narayanan, sp. nov. (Figures 1, 2 \& 3)

\section{Diagnosis:-}

Nanooravia kayyurenseis allied to N. santapaui, in having undivergent recemes; long callus, keel-less and wingless glumes etc., but clearly distinguished by large spikelets, glumes with unauricled, aristate apex.

Corresponding Author:- T. Shaju.

Address:- Plant Systematics and Evolutionary Science Division, Jawaharlal Nehru Tropical Botanic Garden and Research Institute, Karimancode P.O, Palode, Thiruvananthapuram - 695 562, Kerala, India. 
Type: India, Kerala, Kasaragod district, Kayyur, 20 September 2017, T. Shaju, M. Rajendrapasad \& M.P. Rijuraj, 91178 (Holotype TBGT!;Isotype MH!).

\section{Description:-}

Annuals. Culms up 60-70 cm tall, erect, slender; nodes bearded. Leaves all along the culms; sheaths $4-7 \mathrm{~cm}$ long, keeled on the back; ligule membranous, up to $0.1 \mathrm{~mm}$ long, fimbrtiate- truncate at apex; blade $5.5-6 \mathrm{~cm} \times 3.5-4 \mathrm{~mm}$, linear-lanceolate, basally keeled, acute to acuminate at apex, slightly cuneate or rounded at base, margin thick, beset with long bulbous based hairs more profuse towards the base and sparsely on the margins and near margins towards apex. Racemes 2, usually unequal, inter-twined, well exerted from the uppermost sheath, $5-7 \mathrm{~cm}$ long; rachis triquetrous, glabrous; pedicels 2-2.8 mm long, joints oblique, glabrous. Callus 2-2.5 mm long, trigonus, cuneate at base, obliqe at apex, densely covered with golden yellow hairs. Spikletes linear oblong-oblanceolate, 9-10.5 mm long, distantly arranged along the rachis. Lower glume crustaceous, linear-lanceolate, rounded on the back, margins entire, membranous, partly hyaline, delicate, not auricled, echinate, acuminate-aristate at apex, $5.5-6.5 \mathrm{~mm}$ long including the arista of $1 \mathrm{~mm}$ long. Upper glume crustaceous, oblong-lanceolate, rounded on the back, 9.5-10.5 mm long, oblong lanceolate, margins entire, faintly ciliate at middle, membranous, partly hyaline, delicate, not auricled, echinate, acuminate-aristate at apex with a few long hairs, 9.5-10.5 mm long including the arista of 3-3.5 mm long. Lower floret empty; lemma hyaline, linear-elliptic-lanceolate, 1-nerved, 4- 4.5 x 0.7-1 mm long, retrosely ciliate along margin, acute tip. Upper floret bisexual. Upper lemma hyaline, linear-lanceolate, 5-6mm long, 1-nerved, apex bifid with acute lobes, lobes $1 \mathrm{~mm}$ long; awn stout from the sinus, awn up to $6.5 \mathrm{~cm}$ long with a column 3-3-5 cm, twisted, scaberulous-pubescent with pale bristiles. Palea small, 0.7-1 mm long, elongate-triangular, hyaline, papillate towards upper half. Lodicules 2, ca. O.3 mm long, truncatly lobed at apex. Stamens 2, anthers 2-2.5 mm long, yellow. Grains oblong- elliptic, ca. 3-3.5 mm long, subacute at apex, closely adpressed with the basal part of the palea.

Table 1:- Comparison of charecters between Nanooravia santapaui and N.kayyurense.

\begin{tabular}{|c|c|c|}
\hline & Nanooravia santapaui & N.kayyurense \\
\hline Leaf & $\begin{array}{l}\text { Aggregated; blades linear-subulate, } 2-5 \mathrm{~mm} \\
\text { long, margin with few bulbous based hairs }\end{array}$ & $\begin{array}{l}\text { Scattered; blades linear-lanceolate, } 5-6 \mathrm{~mm} \\
\text { long, Bulbous based hairs profusely at base and } \\
\text { sparsely on margin towards apex }\end{array}$ \\
\hline Spikelets & $5-6 \mathrm{~mm}$ long & 9-10.5 mm long \\
\hline Lower glume & $\begin{array}{l}\text { 4-4.5mm long, linear-oblong, margins } \\
\text { coriaceous, auricled at apex }\end{array}$ & $\begin{array}{l}5.5-6.5 \mathrm{~mm} \text { long, linear-lanceolate, margins } \\
\text { hyalined, not auricled, aristate at apex }\end{array}$ \\
\hline Upper glume & $\begin{array}{l}5-5.5 \mathrm{~mm} \text { long, oblong-lanceolate, auricled at } \\
\text { apex }\end{array}$ & $\begin{array}{l}9.5-10.5 \mathrm{~mm} \text { long, oblong lanceolate, margins } \\
\text { hyalined not auricled, aristate at apex }\end{array}$ \\
\hline Lower lemma & $\begin{array}{l}\text { 3-4 mm long, oblanceolate, sparsely ciliate } \\
\text { margins }\end{array}$ & $\begin{array}{l}\text { 4- } 4.5 \mathrm{~mm} \text { long, linear-elliptic-lanceolate, } \\
\text { retrosely ciliate margins }\end{array}$ \\
\hline Upper lemma & 3-4 mm long, oblanceolate & 5-6mm long, linear-lanceolate \\
\hline $\begin{array}{l}\text { Awn of upper } \\
\text { lemma }\end{array}$ & $2.2-3 \mathrm{~cm}$ long with a column up to $1.2 \mathrm{~cm}$ & $6-6.5 \mathrm{~cm}$ long with a column up to $3.5 \mathrm{~cm}$ \\
\hline Palea & $\begin{array}{l}\text { c. } 0.5 \mathrm{~mm} \text { long, ovate-lanceolate, shortly ciliate } \\
\text { along margins }\end{array}$ & $\begin{array}{l}\text { c. } 1 \mathrm{~mm} \text { long, elongate-triangular, papillate } \\
\text { towards the upper half }\end{array}$ \\
\hline Stamen s & $1-1.5 \mathrm{~mm}$ long, yellow to reddish & 2-2.5 mm long, yellowish \\
\hline Grains & $\begin{array}{l}\text { 2-2.5 mm long, linear-oblong, subcompressed, } \\
\text { acute-apiculate at apex }\end{array}$ & $\begin{array}{l}\text { 3-3.5 mm long, oblong- elliptic, not compressed, } \\
\text { subacute at apex }\end{array}$ \\
\hline
\end{tabular}

\section{Phenology:-}

Flowering \& fruiting: -September - November

\section{Etymology:-}

The new species is named after the type locality 'Kayyur' in Kasaragod District of Kerala State, India. Kayyur is known for the historic agrarian revolt in 1940 (known as 'Kayyur rebellion') by peasants of the village against feudalism under the leadership of communists. Several people were killed in the incident and four communist leaders were hanged to death by the government. 


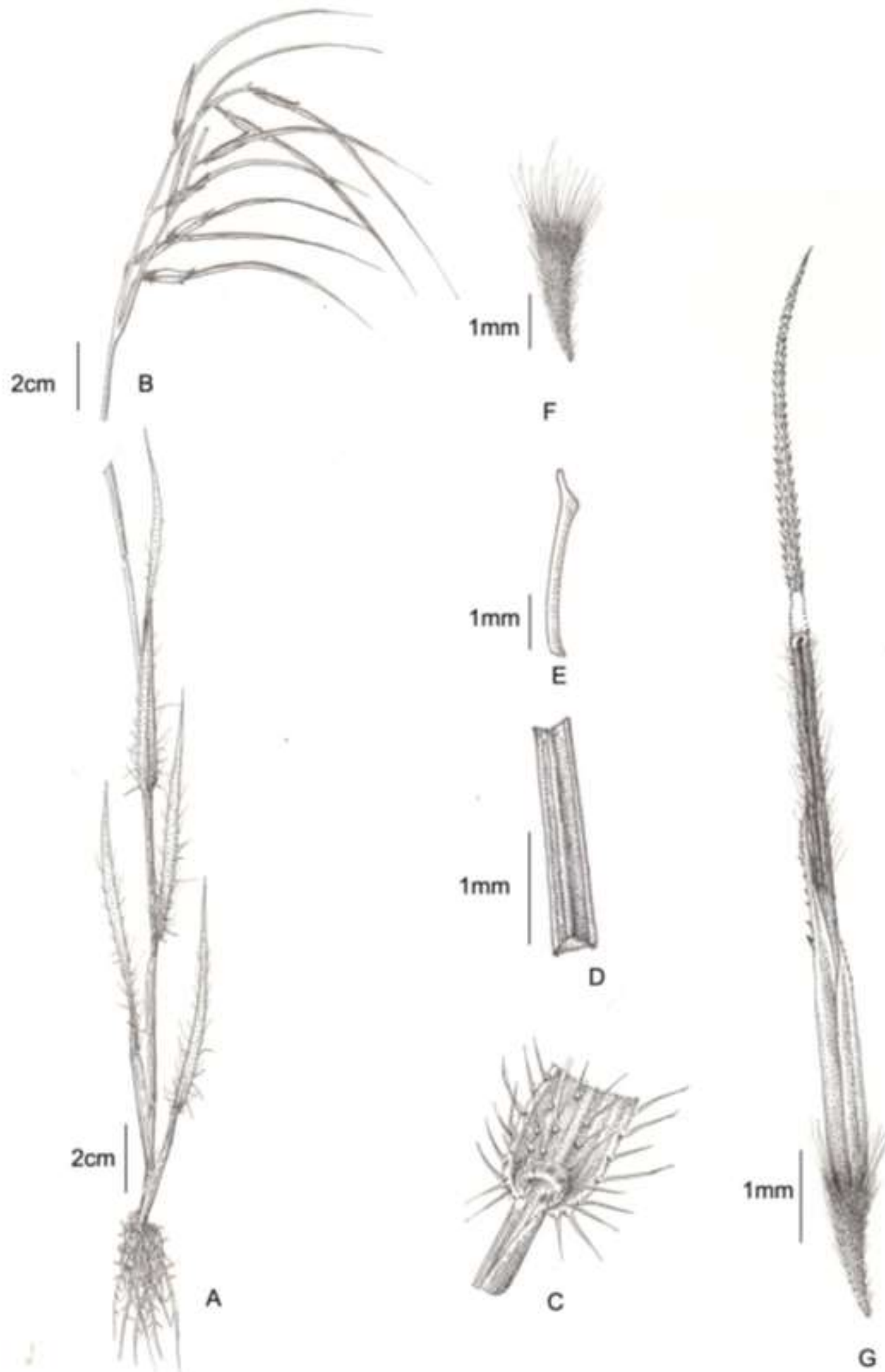

Figure 1:- Nanooravia kayyurense. A. Habit ; B. Inflorescence; C. Leaf base with ligule; D. A portion of rachis; E. Pedicel; F. Callus; G.Spikelet 

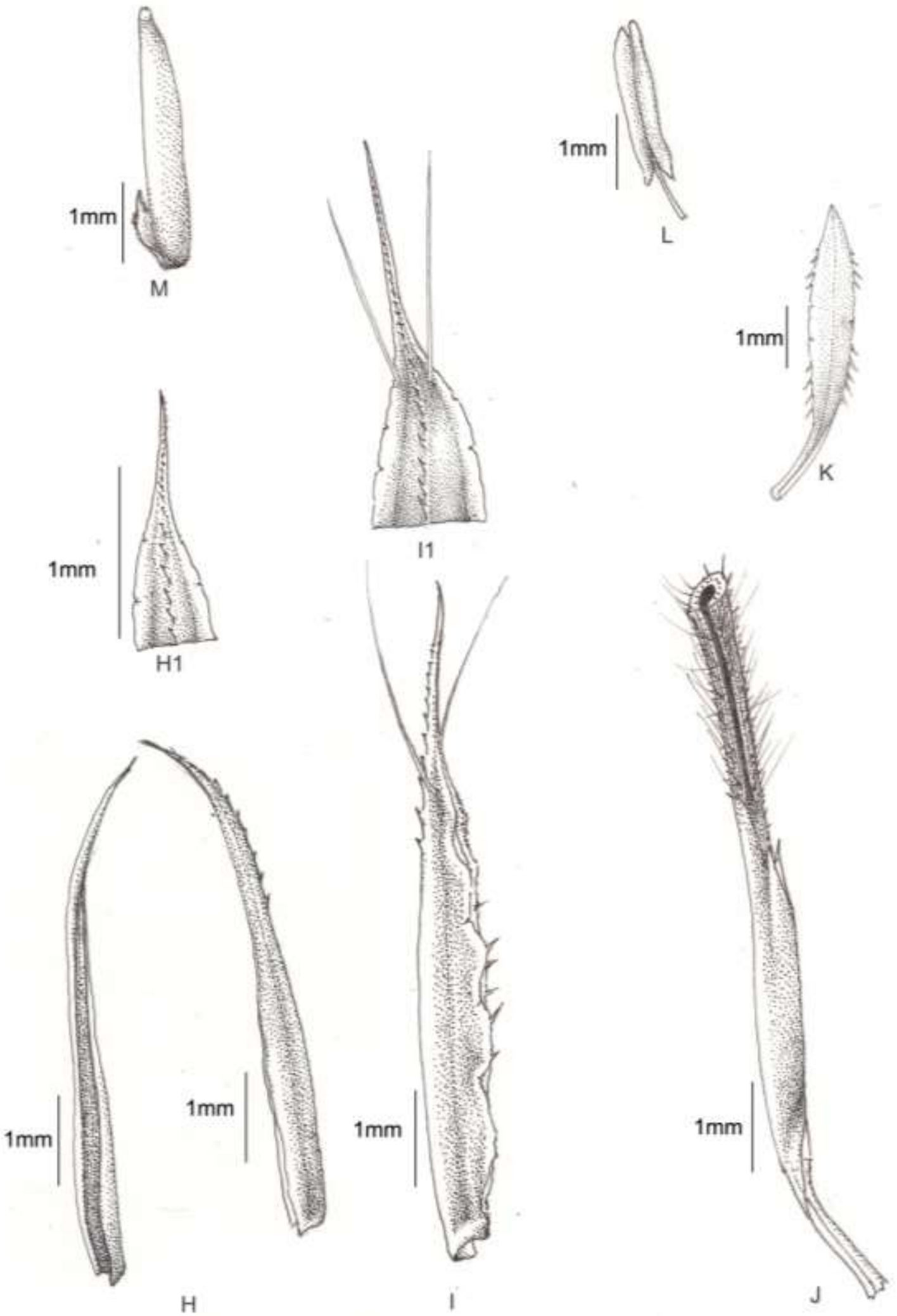

Figure 2:- Nanooravia kayyurense. H.Lower glume, ventral and lateral view; $\mathrm{H}^{1}$. Apical portion of lower glume, dorsal view; I. Upper glume, Lateral view; $\mathrm{I}^{1}$. Apical portion of upper glume, dorsal view; J. Upper lemma, lateral view; K. Lower lemma; L.Stamen; M.Grain with basally attached palea 

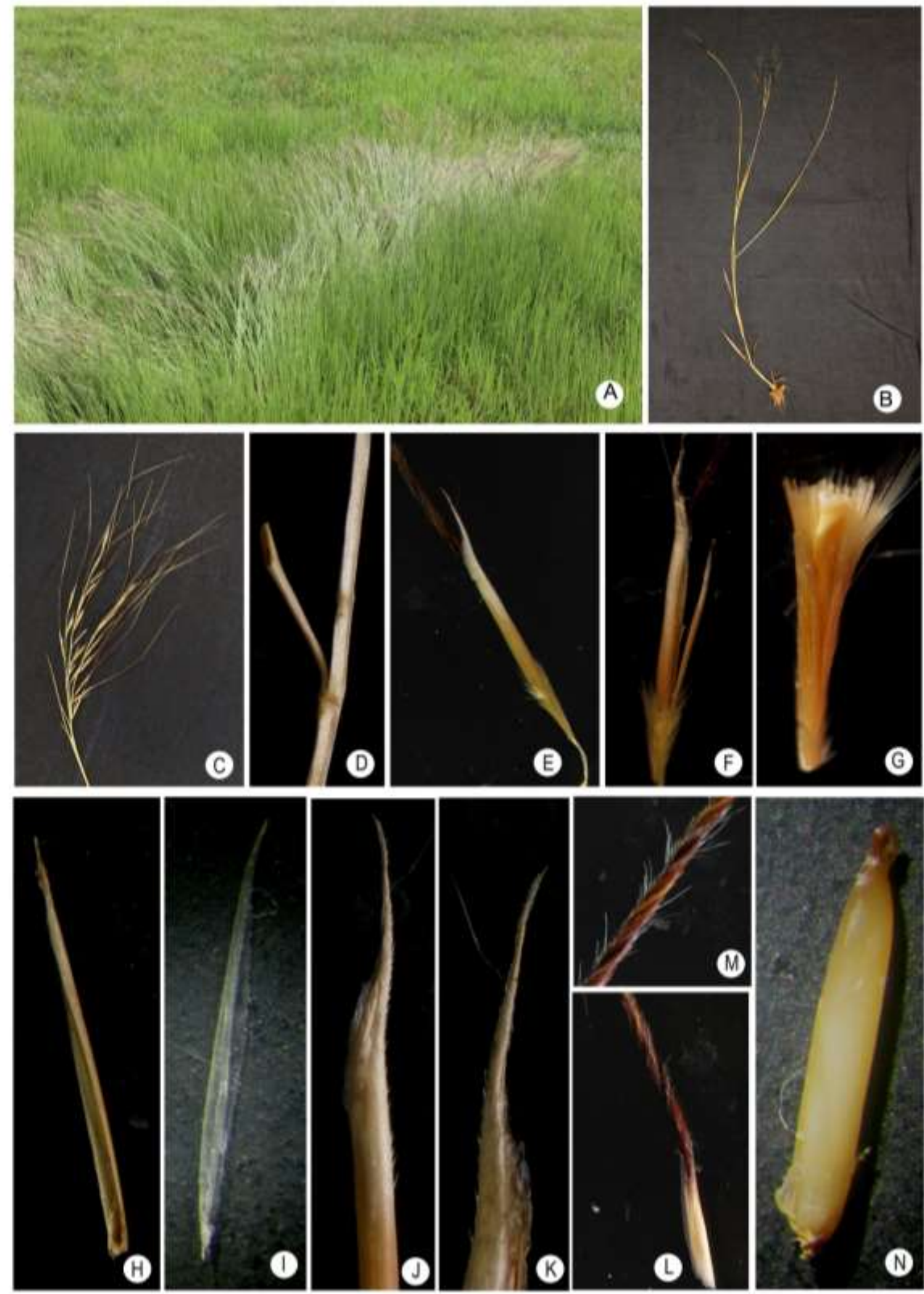

Figure 3:- Nanooravia kayyurense. A.Habitat; B. Habit; C. Inflorescence; D. Rachis with pedicel; E \& F. Spikelet; G. Callus; H. Lower glume; I. Lower lemma; J. Upper glume; K. Apical portion of upper glume; L. Upper lemma; M. A portion of awn enlarged; N. Grain with basally attached palea 
Distribution and ecology: Apart from the type locality, Kayyur, the species is not currently known from anywhere else. It grows gregariously in the ephemeral wetlands of the area, forming intermittent patches. The species shows seasonal variation in flowering and fruiting from other grasses of the post-monsoon phase. Nevertheless, it is associated with the monsoon species such as, Eriocaulon spp., Isachne kannurense Sunil et al., Burmania coelestis D. Don, Rhynchospora wightiana (Nees) Steud., Xyris indica L. and Schoenoplectiella lateriflora (Gmel.)Lye.

Notes: The Peninsular Indian region has always been considered as an oceanic island in having conditions favourable for high degree of endemism (Turrill, 1964). Lateritic plateaus of the region provide smaller scale habitats with hydro-geo-morphological anomalies that support significant plant taxa, especially endemic species in restricted areas. Grass dominated habitats form an important constituent of the lateritic vegetation in Peninsular India. The tribe Andropogoneae shows maximum diversity and endemism as compared to the species diversity of other grass tribes. Based on phylogenetic studies, Andropogoneae is considered monophyletic in origin and described as forming a natural group because of the many similar morphological features exhibited by the constituent taxa. Thus it forms a successful group in Peninsular India, the Western Ghats in general and Kerala in particular. The rich species diversity and high degree of endemism indicate that the group is actively evolving in the Kerala region of the Western Ghats, especially along the lateritic hillocks. These factors substantiate the view that the lateritic plateaus of Peninsular India are an abode of several neoendemic species, especially considering the high degree of narrow/local/point endemism exhibited by the genus Dimeria and recognition of the new genus Nanooravia in the subtribe Dimeriinae of tribe Andropogoneae. The proposal of new species N. kayyurense further proves the novelty of the tribe in Kerala.

\section{Justification for retention of Nanooravia}

The subtribe Dimeriinae Hack. ex C.E. Hubb. (1934) is distinguished by espatheate inflorescence consisting of 1-11 digitate racemes with tough rachis and solitary spikelets with which it differs from all other subtribes of Andropogoneae Dumort. The fact that the majority of the species are confined to Peninsular India (Hackel, 1889; Hooker, 1896; Bor, 1953; Kiran Raj, 2008; Kiran Raj et al., 2013a, b) and it indicates Peninsular India to be the centre of speciation of the subtribe, is further justified with the segregation of the new genus Nanooravia Kiran Raj \& Sivad., based on Dimeria satapauii (Kiran Raj et al., 2013a). The subtribe Dimeriinae now comprises two genera, viz. Dimeria and Nanooravia. The close resemblance of inflorescence in their general morphology and coexistence of species of the two genera in the same geographical region signify a close relationship of the two, despite the differences in their floral characters.

According to Kellog (2015), description of the monospecific genus Nanooravia was solely based on Dimeria santapaui, in which the spikelets are not strongly compressed, and the glumes bear auricles at the apex. Further, recognition of the species as belonging to a new genus was regarded premature, and suggested its retention in Dimeria which was not corroborated by Veldkamp (2016). The characters of the new species, $N$. kayyurense further strongly support the segregation. The unique characteristics such as non-divergent, unequal and inter-twined racemes with distantly arranged large spikelets, long callus, and keel-less, and wingless glumes with dorsally rounded echinate apex manifested by both $N$. santapaui and $N$. kayyurense make clear distinction of Nanooravia from the genus Dimeria. The new species $N$. kayyurense is allied to N. santapaui in having non-divergent racemes, long callus, and keel-less, wingless, dorsally rounded glumes, among others, but distinguished particularly by large spikelets, non-auricled glumes, and aristate apex.

\section{Acknoledgements:-}

The authors wish to express their sincere gratitude to Dr. A. G. Pandurangan, Director, Jawaharlal Nehru Tropical Botanic Garden \& Research Institute (JNTBGRI), who provided facilities and encouraged the authors in their research activities. The authors are grateful towards Dr. M. Sivadasan, Former Professor, Department of Botany \& Microbiology College of Science, King Saud University, Riyadh, for a critical review of the manuscript and Dr. J. F. Veldkamp, Leiden, for valuable comments . Encouragement provided by Dr. C.N. Sunil, Former Associate Professor, Department of Botany, S. N. M. College, Maliankara is thankfully acknowledged. They are also thankful to Dr. P. K. Shaji, Principal Scientist, ERRC, Thiruvananthapuram and S. M. Shareef, Technical Officer, JNTBGRI for the encouragements. Thanks are also due to the Kerala State Council for Science Technology and Environment, Kerala, for providing financial support. 


\section{References:-}

1. Bor, N.L. 1953. Notes on Asiatic Grasses XI. The genus Dimeria R. Br. In India and Burma. Kew Bull. 1952 (7): $553-592$.

2. Clayton, W. D. \& Renvoize, S. A.1986.Genera Graminum.Grasses of the World.Kew Bull. Add. Ser.XIII. pp. 1-39.

3. Hackel, E. 1889. Dimerieae. In: A. and C. de Candolle, Monographiae phanerogamarum 6. G.Masson, Paris, pp. 76-90.

4. Hackel, E \& Hubbard C.E. 1934. The Families of Flowering Plants.II.Monocotyledons 227.

5. Hooker, J. D. 1896. Dimeria. In: Hooker, J.D. (Ed.), Flora of British India, 7. Reeve \& Co. Ltd., London, pp. 103-106.

6. Kellog, E.A. in Kubitzski, K. 2015. Families and Genera of Vascular Plants: XIII. Flowering Plants - Monocots. Poaceae. Springer International Publishing Switzerland, pp. 289-314.

7. Kiran Raj, M .S. 2008. Taxonomic revision of the subtribe Dimeriinae Hack. Of Andropogoneae (PoaceaePanicoideae) in Peninsular India.- Ph.D Thesis, University of Calicut.

8. Kiran Raj, M. S., Sivadasan, M., Veldkamp, J. F., Alfarhan, A. H. and Thomas, J. 2013a. Nanooravia gen. nov., subtribe Dimeriinae (Poaceae-Panicoideae-Andropogoneae) from India. Nordic. J. Bot. 31: 161-165.

9. Kiran Raj, M. S., Sivadasan, M., Veldkamp, J. F., Alfarhan, A. H. and Jacob Thomas 2013b. Validation of Nanooravia santapaui (Poaceae - Panicoideae - Andropogoneae - Dimeriinae) - Nordic Journal of Botany 31: $161-165$.

10. Sreekumar, P. V. \& Nair, V. J. 1991.Flora of Kerala - Grasses. Botanical survey of India, Kolkatha, 80-101.

11. Turril, W. B. 1964. Plant Taxonomy, Phytogeography and Plant ecology. In: Vistas in Botany, vol. IV Pergamon Press. London

12. Veldkamp J.F. 2016. A Revision of Dimeria ( Gramineae- Dimeriinae)in Malesia with a note on Cymbachne. Volumes 61: 207-214. 